\title{
The Power of Language in Indonesia's Reformation
}

\author{
Randi Muchariman Universitas Siliwangi, Indonesia
}

\begin{abstract}
Indonesia's Reformation in 1998 is a political change driven by the power of civil society and very much determined by the discourse in hegemonic struggle. One of the most influential intellectual ideas and leadership styles of reformation and civil society is suggested by Nurcholish Madjid. This writing examined the twenty-year problems of Reformation in the view of Gramsci's theory of hegemony by analysing Nurcholish Madjid's ideas. There is an intellectual imperialism which makes the national ideas embedded in the Preamble of the 1945 Constitution unable to be developed to guide the national life due to the irrelevant social sciences. The explanation will show the possibilities and the expectations after twenty years of Reformation in Indonesia.
\end{abstract}

Keywords:

Reformation; Hegemony; Nurcholish Madjid; the Preamble of the 1945 Constitution

\section{INTRODUCTION}

The Reformation Movement is

indicated by the demands of Soeharto's resignation as the President of Republic of Indonesia and of four other demands, which were the amendment of the 1945 Constitution, the eradication of KKN (Korupsi, Kolusi, dan Nepotisme Corruption, Collusion, and Nepotism), the revocation of five Political Laws, and the revocation of Dwifungsi $A B R /$ (Dual Function of Indonesian Armed Forces).

Randi Muchariman is a lecturer at Department of Political Science, Universitas Siliwangi, Indonesia. His research focus on Culture, Religion and Politics. E-mail: randi.much@gmail.com.

Author thanks to all colleagues in Faculty of Social and Political Science, Universitas Siliwangi. Thanks to Faris Salman and Ina Minasaroh for excellent comments on earlier draft as well as feedback from participant at International Symposium on Indonesian Politics 2018. Author also thanks to anonymous reviewer for their comments.
Substantially, the Reformation Movement is a correction of the New Order Regime and an effort to restore the government to the ideal of 1945's Proclamation (Arsil et al, 2016). Therefore, one of the most important debates of Reformation is about the ideal of 1945's Proclamation itself.

To measure or assess the Reformation that has been ongoing for almost twenty years, it is necessary to determine the tools or concepts to measure or assess it first. This statement is essential since it will show how a fact is explained as reality. The achievement of it will be very much determined by the mastery of language of concepts used in the discourse of Reformation. It is exemplified by a situation in which a lecturer asks his students, "What will be said by an animal when a human torture 
it?" The students in the class are confused because animals cannot speak or use any language understood by humans. In such confusion, the lecturer answers his own question that humans need language(s) or concepts to explain what is experienced and going to be done by them. Humans will be limited by language use or functioning in their social and cultural life (Halliday et al, 1992; Horkheimer et al, 2002).

This writing, first, will show the analysis of a discourse on reformation and civil society initiated by Nurcholish Madjid to show the influence of language functioning on the context of sociopolitical change in Indonesia. The analysis will show the direction and quality of change caused by language use in the discourse. For this purpose, the analysis of how to assess the Reformation that has been being carried out up to now will be pointed out in this part. It is an effort to show how the assessment of Reformation is correlated with the language functioning which is consistent with what has been done by Nurcholish Madjid as explained above.

In the second part, this writing explains the analysis of the possibilities and the expectations after twenty years of Reformation based on the previous analysis. In this part, the intellectual agenda and the political change are discussed and examined using the analysis of political power in Indonesia. The agenda and idea are directed to be a new discourse for the purpose of constructing an explanation of the ongoing hegemony in national life. This writing, to explain the discourse and hegemony, tries to make a textual interpretation of the Preamble of the 1945 Constitution as the ideal constitution and values. This writing is an initial effort to construct a great idea in developing social sciences that are relevant to Indonesia based on the understanding of the result of analysing critical discourse on the text of Preamble of the 1945 Constitution.

\section{Civil Society and Idea of Reformation}

The idea of political reformation disseminated by Nurcholis Madjid is rooted in the idea of civil society that is contextualised in Indonesia's sociopolitical situations so that it uses a term masyarakat madani as its synonym (Hefner, 2001; Suminto, 1985; Maula, 1999). Choosing the synonym aims to build a discourse mainly in a community or a society of Indonesian Muslims that 
are modernistic and liberal (Assyaukanie, 2011; Barton, 1999).

The discourse constructed by Nurcholish Madjid has shown two important things in the initial process of Reformation Movement so that it can provide identity or definition for the movement (Gaus, 2010). First, the term masyarakat madani shows that it is aimed at the message recipients among Muslims that, as the majority, they are still regarded as the determinant of the success of the movement. The political power of Muslims before Reformation was consolidated. One of the consolidations was in an organisation named The Indonesian Association of Muslim Intellectuals (ICMI, which stands for Ikatan Cendikiawan Muslim seluruh Indonesia).

The second important thing of choosing the synonym shows the dependency on the idea of civil society to define the Reformation Movement. Nurcholish Madjid has tried to suggest that the idea of civil society is in line with and supported by Islamic doctrines. In his opinion, civil society has its roots in the Islamic history since the era of Muhammad's prophecy. The dependence on the idea of civil society has actually shown the hidden interest in the agenda of Reformation.

Using Norman Fairclough's critical discourse analysis, Muchariman (2016) mentions that the main purpose of Nurcholish Madjid's idea of reformation is closely related to the interest of globalisation process after the fall of the Soviet Union (USSR). This idea is built based on a rhetoric compiled of the construction of discourse on civil society (Muchariman, 2016).

The result of critical discourse analysis of Nurcholish Madjid's discourse on civil society is that it actually has interests of globalisation after America's victory over the Soviet Union in the Cold War. In the discourse, globalisation is a process of disseminating liberal democracy as the winner after the fall of the Soviet Union. Nurcholish Madjid's discourse states that participating in the globalisation is one of the most important things which are related to the national security in dealing with the changing sociopolitical order. It means that if Indonesia's national sociopolitical order does not change along with the international changes, the national security will be in a threatened condition. Therefore, the offer given by the discourse is a process of sociopolitical reformation. 
In short, Nurcholish Madjid states that Indonesia must carry out a sociopolitical reformation by following the global aspiration -as mentioned by Fukuyama (2004) — to be in line with the idea of liberal democracy. And to make people of the text readers agree with the idea, the discourse of masyarakat madani that is synonymous with civil society is constructed to be a discourse that is influential in the changes of social practice (Baso, 1999; Edwards, 2011).

The formula of sociopolitical reformation of Nurcholish Madjid's discourse has affirmed that the intellectual ideas and leadership are in the power structure called hegemony. Hegemonic class has interests in strengthening their power and it can only be done if it is suitable with the interests of the intellectual leadership with all of their ideas (Simon, 2004: 27, 55). The result of critical discourse analysis in Muchariman's thesis states that Reformation does not substantially refer to the ideal of Proclamation as written in the Preamble of the 1945 Constitution. However, reformation is basically a hegemonic manifestation of the capitalist class that tries to defend and even reproduce their power.
The conclusion can be explained because the idea of the intellectual leadership represented by Nurcholish Madjid is suitable (consistent and coherent) with the interests of hegemonic capitalist class. They are neoliberal capitalists who have tried at least since 1947 to ensure the international acceptance of neoliberal idea as the only choice to protect freedom. This neoliberal idea is supported by postmodernism as a dominant culture and way of thinking (Harvey, 2009: 65-70, 161-162).

Choosing the concept of democracy and democratisation based on the concept of civil society and civility underlain by the acceptance of the idea of tolerance and pluralism rooted in the secular worldview and guided by postmodern tradition is the most important thing that shows the interdiscourse changing the existing discourse order so that it affects changes in social practice. Therefore, it can be concluded that the final purpose of the whole discourse is not the existence of a masyarakat madani as defined by the language based on the traditional/conservative Islamic tradition.

There is strong correspondence and coherence between the discourse construction and the sociopolitical condition nowadays. At least it is 
indicated by the failure of the discourse on masyarakat madani initiated by Anwar Ibrahim in 1995 substantially in the political practice in Indonesia. At that time, Anwar Ibrahim is an Islamic figure in Southeast Asia from Malaysia and a disciple of Muhammad Naquib Al Attas who elaborates the concept of masyarakat madani as a manifestation of Islamic ideas as a din (a concept of belief that is usually called religion, but they both are different translator and civilisation (AI Attas, 2010a, 2010b; Smith, 1985). Such a condition is one of the purposes embedded in Nurcholish Madjid's discourse construction.

Finally, in this part, a conclusion should be drawn that Nurcholish Madjid has failed in formulating the structure of discourse and thought to support the Reformation in Indonesia. Reformation in the political field should have been based on the relevant social sciences so that it corresponds and becomes coherent with sociopolitical context and scientific tradition. The failure happens because Nurcholish Madjid has refused the meaning of masyarakat madani suggested by the conservatives or neoconservatives who explain its meaning based on an original review based on the scientific history and tradition suitable with the cultures in Malay-Indonesian archipelago (Al Attas, 1990).

Back to the discussion about interdiscourse and changing discourse order, this writing should show the influence of language (the exact word is text) on social practice. As explained in Norman Fairclough's (1995) critical discourse analysis, text as a functional language will give some influence on choices and understanding in sociocultural context so that it will be social practice. This part explains that Nurcholish Madjid's thought about the necessity of reformation in Indonesia among his other thoughts- has given a big influence indicated by the sociopolitical practice and the texts coming afterwards.

For this purpose, in the following paragraph, the analysis of the assessment of Reformation is done. The assessment in this context means giving values to determine the right position of Reformation in a recognisable system in which the relationship among those in it can be clearly known. The analysis of it is very important to understand what has been applied in Reformation for the last twenty years.

The criticism of this process can be proposed by stating that the analysis 
which has been done is not thorough and unable to show the representation of the existing number (of texts and social practice). Such a claim is not the purpose sought in this writing. Nonetheless, this part aims to show some assessments of the democracy implemented by the hegemonic class as explained in Gramsci's theory of hegemony. In brief, this is the analysis of the meaning of Reformation in the perspective of the hegemonic class.

For this purpose, three texts are going to be analysed, i.e. the summary of the result of a seminar under the title Meluruskan Jalan Reformasi: Merumuskan Pilar-Pilar Pemandu Bangsa at UGM in 2003, an elaborate book published by BPS about Indonesia's Democracy Index entitled Demokrasi Indonesia: Ledakan Tuntutan Publik Vs. Inersia Politik tahun 2011, and Visi Misi Calon Presiden Jokowi Widodo dan Jusuf Kalla tahun 2014.

The summary of the result of seminar Meluruskan Jalan Reformasi has shown the thoughts of the intellectual leaders who at that time had initiated Reformation since the beginning. In the document, it is explained that Reformation is:

"The four demands of reformation are merely an intermediate purpose.
The most essential purpose of $G R$ (Gerakan ReformasiReformation Movement) is the consequent implementation of the values of Pancasila dan the Preamble of the 1945 Constitution in national life and administration".

GR is said as the reaction against the emasculation of the ruling class' democratic rights. The explanation of the Preamble of the 1945 Constitution in the document is related to democracy. In one of the parts regarding government, the terms good governance and civil society are used to explain the slowness of Reformation process.

The most important thing that should be concluded from the document is regarding consistence and coherence of the use of the various concepts written with the document of the Preamble of the 1945 Constitution that is stated (in the document itself) as a document referred or a text which affects the text. It means the text mentions that it is influenced and even a continuity of the text of the Preamble of the 1945 Constitution, but the text itself does not show the use of key concepts used by the text of the Preamble of the 1945 Constitution.

An example of it is the use of the word democracy in the text six times while the word musyawarah is not used 
at all. Comparing between democracy and musyawarah is an important example for several reasons. First, the word musyawarah is used in the text of the Preamble of the 1945 Constitution while the word democracy is not. A word or a phrase that probably has the same meaning as democracy in the text of the Preamble of the 1945 Constitution is kedaulatan rakyat (people's sovereignty) whose meaning is tied by the following sentences in the fourth paragraph containing the words permusyawaratan /perwakilan (deliberation/representation). It means that the meaning of kedaulatan rakyat written in the Preamble of the 1945 Constitution is actually tied by the concepts explained in the following sentences. Therefore, the explanation of democracy juxtaposed with civil society shows the whole meaning that is different from kedaulatan rakyat juxtaposed with permusyawaratan/perwakilan.

Second, the conclusion in the first cause shows that there is hegemony prevailing in the thought written in the text of summary of the seminar result. The prevailing hegemonic process in Nurcholish Madjid's discourse as explained above actually prevails in the other intellectual leadership in the discourse on Reformation in Indonesia.
The second text to be analysed is a book published by BPS about the Index of Indonesian Democracy entitled Demokrasi Indonesia: Ledakan Tuntutan Publik Vs. Inersia Politik tahun 2011 (it is going to be called IDI text). IDI text explains that IDI is a tool to measure the development of democracy which is typically Indonesian. In the Introduction written by the Minister of Coordination of Political, Law, and Security Fields, IDI is explained as follows:

"IDI is compiled to help the government make development planning in political field. Thus, IDI is actually not a tool to evaluate the government's work performance because the component that forms the indicator, variable, and aspect of IDI does not only measure the scope of governmental work but also the growing democracy in society at the same time." (Rauf, et.al., 2011: vii).

If IDI is part of Reformation which means 'to return to the substance of Indonesia's independence in 1945 reflected in the text of the Preamble of the 1945 Constitution, the development of democracy which is typically Indonesian should have been suitable with the text of the Preamble of the 1945 Constitution. IDI text mentions, in the speech of the Minister of Perencanaan Pembangunan Nasional (PPN/National Development Planning) the Head of Bappenas, that 
democracy which is typically Indonesian is based on the values of the national philosophy: Pancasila and the 1945 Constitution (Rauf, et.al., 2011: xi). However, in the explanation of the next part in $|D|$ text, it is stated that the typically Indonesian democracy is that the method of IDI measurement considers the uniqueness of Indonesian problem. Generally, it means 'the reality of shifting relation between the state and the society after the New Order Regime'. Therefore, it is clear that the democracy that is meant in IDI text is not kedaulatan rakyatpeople's sovereignty as meant by the text of the Preamble of the 1945 Constitution.

The conclusion is confirmed at least by several things. First, both IDI text and IDI were first supported by UNDP (United Nations Development Programme or Program Pembangunan Perserikatan Bangsa-Bangsa) and not by the government independently. It means that the various interests of UNDP as an actor outside the state and the society cannot be ignored. The values inherent in UNDP should not have been the determinant of IDI text, but it is the substance in the Preamble of the 1945 Constitution which should be the determinant.
Second, the concepts used in IDI in fact tend to show the values of UNDP as part of the United Nations. The three indexes in IDI, which are the aspect of civil freedom, the aspect of political rights, and the aspect of democratic institution, can be concluded as manifestation of the values embedded in the Universal Declaration of Human Rights (1948) one of which consists of the rights of civil and political freedom that are then written in the International Covenant on Civil and Political Rights (1966). Both of the texts came after the Preamble of the 1945 Constitution and not an explanation of the text of the Preamble of the 1945 Constitution.

Third, the concept of democracy used by the IDI text is the binary opposition of the word authoritative (otoriter). This narrative of knowledge emerges from the European history that becomes the background on the Western civilisation and the source of colonisation in MalayIndonesian Archipelago. Although the narrative is used to show a context of the change towards democracy or like the wave of democratisation (Huntington, 1997) in the last decade, it cannot be denied that such a worldview is sourced from the Western worldview with all of the fundamental characteristics and history 
(Al Attas, 2000: 18-27). In conclusion, IDI text shows that the hegemonic process is still ongoing and manifested in the intellectual imperialism. Hegemony is ongoing by ensuring the agreement to certain awareness because there is common sense in society where the power takes place.

The third text to show the ongoing hegemony is the vision and mission of the presidential and vice-presidential candidate pair number two that was elected as president and vice president of the Republic of Indonesia in 2014-2019. The third text (later called text June 1) is chosen to show how reformation is assessed and interpreted by the men in power (rulers) and how the agreement to text is done as a consensus in the political practice which basically indicates that an authority of hegemony is in force.

The third text is named June 1 because it assesses Reformation and contains the explanation of Pancasila ideology June 1. Text June 1 is indeed about the Preamble of the 1945 Constitution as the source of ideological way that is a way of change for Indonesia's Reformation that has undergone uncertainty in a prolonged transition to Indonesia that is more democratic. Nevertheless, in the next explanation, the Preamble of the 1945 Constitution is explained as "having mandated the direction of national goals behind the formation of the Unitary State of the Republic of Indonesia (in the correct history and text, the term used is the State of the Republic of Indonesia). Meanwhile, Indonesia's identity as an independent and sovereign state is based on the Proclamation and Pancasila June 1 1945. Thus, text June 1 only takes some part of the Preamble of the 1945 Constitution while the meaning of Reformation is substantially determined by Pancasila June 11945.

Text June 1 confirms that Reformation will be able to run as expected if guided, moved, united, and directed by the ideology of Pancasila June 11945 and Trisakti both of which were created by Soekarno. Pancasila June 1 1945 was born before the Preamble of the 1945 Constitution which was first born in its earliest form on June $22^{\text {nd }}$, 1945. Meanwhile, Soekarno's Trisakti was born in 1963 when he had applied Manipol USDEK.

Through the last text analysed, the conclusion about Reformation can be described this way: that Reformation interpreted as 'to return to the ideal of the 1945 Proclamation with the Preamble of 
the 1945 Constitution as its explaining text because of having interdiscourse relation with it' is not consistent with interdiscourse and the result of critical discourse analysis of the texts after Reformation. In the third text, Reformation is interpreted with Pancasila June 11945 and Trisakti created by Soekarno which are different from the Preamble of the 1945 Constitution.

The difference can be for example identified from the use of two concepts placed as synonyms in Soekarno's speech on June $1^{\text {st }}, 1945$, known as Pancasila June 1 . The two concepts are mufakat (consensus) and democracy. The word mufakat is used to show the meaning of democracy and not vice versa. The word mufakat in Pancasila June 1 is also considered synonymous with the word musyawarah (deliberation), but, in its explanation, the word musyawarah is used to show the meaning of democracy and not vice versa. There is a difference of worldviews that becomes the basis for the semantic field in Pancasila June 11945 and in the Preamble of the 1945 Constitution.

After Twenty Years of Reformation and the Discourse on the Preamble of the 1945 Constitution
Nurcholish Madjid's discourse on masyarakat madani (civil society) in the years before Reformation played an important role in ensuring the direction of change expected by the power of Political Islam by making sure that common sense of the majority of the political power accepted the idea of democracy and democratisation. In a more detailed and specific way, the discourse has distracted and hindered the development of another idea about masyarakat madani which is more suitable with the scientific tradition of Indonesian Muslims supporting the Political Islam that, in the years before Reformation, took part in a discourse on the sociopolitical practice in Indonesia.

This is why Nurcholish Madjid's discourse becomes important in this writing, which tries to show the problem regarding Reformation in Indonesia: that Reformation is a change related to the sociopolitical practice in Indonesia and a change in the sociopolitical practice means a change in the discourse order. And the critical discourse analysis of Nurcholish Madjid's discourse on masyarakat madani (civil society) has shown that Reformation is ongoing in a dependence of ideas in the intellectual imperialism (Alatas, 2000). 
If Reformation means 'to return to the substance of the ideal of Indonesia's independence in 1945', it can be said that the ideal of the independence does not even intellectually determine the changes which become a consensus or hegemony towards Indonesian society. The conclusion is drawn by doing the comparing analysis of the discourse order of hegemony in Reformation and the textual analysis of the Preamble of the 1945 Constitution. The discourse order of Reformation is constructed based on the Western scientific tradition and sourced from the culture that legalised the colonisation in Malay-Indonesian Archipelago while the discourse order of the Preamble of the 1945 Constitution will be relevant if interpreted based on the Islamic scientific tradition mainly before Western civilisation changed it through the various colonial policies.

To explain the last paragraph above, this writing will analyse the Preamble of the 1945 Constitution first to make it clear and understandable. For this purpose, this writing will discuss Jurnal Ketatanegaraan published by Lembaga Pengkajian (study institute) of MPR (Majelis Permusyawaratan Rakyat or People's Consultative Assembly) regarding the Preamble of the 1945 Constitution, followed by the writer's idea of the Preamble of the 1945 Constitution that shows an analysis of the text as a discourse order based on the Islamic scientific tradition as mentioned in the preceding paragraph.

In the journal, some conclusions can be written as follows:

1. The explanation of the Preamble of the 1945 Constitution does not use discourse analysis and or see the semantic field of the text.

2. The theme regarding masyarakat madani in the journal refers to civil society.

3. The Preamble of the 1945 Constitution is explained through Pancasila or Pancasila becomes the explanation for the Preamble of the 1945 Constitution. Specifically, Pancasila refers to Soekarno's speech on June $1^{\text {st }}$, 1945.

4. The Preamble of the 1945 Constitution is explained through sociopolitical context in the Western history and culture while the Islamic history and culture are ignored. In several writings, the use of the word Allah is discussed as an error in writing the result of 
meeting that should have used the actually the right of every nation" as an word Tuhan (God). example to explain how the Preamble of

5. The Preamble is not explained in a the 1945 Constitution is interpreted by review of Natural View (or Islam. The explanation of the three words worldview) so that it cannot be will be interrelated because it is a part of traced as a text which contains key the whole text. The first word is concepts and certain epistemology. kemerdekaan (independence) rooted from

The five things in conclusion have the word merdeka (independent). This shown that the Preamble of the 1945 word is often translated as 'free of Constitution as the substance in the ideal colonisation and able to take care of of independence that becomes the itself'. In the war of revolution, principle of Reformation has positioned independence became the slogan of the West as the explanation for the struggle that read "merdeka atau mati" meaning it contains and tended to ignore (be independent or die). The word Islam or Islam has been placed as the merdeka etymologically comes from the object that is hegemonised. This word maharddhika which means 'monk, statement is important because the idea sacred, wise, or pious'. Therefore, in this writing states that the Preamble kemerdekaan means 'a situation which is will actually be more consistent to itself suitable with wisdom, with al-ilmu (it is (as a text which has a discourse order) if usually called science, but the meaning is its meaning is explained by positioning Islam as its explanation. Islam as a actually not really the same-translator), with self-control of the destructive lust, worldview or natural view will make the Preamble of the 1945 Constitution able to correspond and become coherent with the scientific tradition of the majority of Indonesian society that are Muslims. Thus, Reformation will be more valuable because it will be abler to make a change in social practice.

This writing will give three words in the sentence "That independence is and with guarding process of the sanctity of life'. If the word merdeka is interpreted with the Islamic worldview, it will contain the concept of al-ilmu and the concept of human life in the world. The concepts of iffah, wara, taqwa, and shiddiq are contained in it. Hence, the meaning of slogan of Revolution merdeka atau mati is actually 'hidup mulia atau mati syahid (live nobly or die a martyr), that is based 
on the Islamic scientific tradition, history, and culture.

The second word is hak which in the other writing is translated as hak asasi manusia and then connected with human rights of the United Nations. In Islam, hak is one of the most important concepts with two meanings, which are kebenaran ([the] truth) and realitas (reality). The word hak is the antonym of the word batil which means 'false' or 'not accord with reality'. The word hak also contains the concept of God which becomes the fundament of the truth and reality themselves. Therefore, the sentence "That independence is actually the right..." means that living nobly, being takwa (pious) and true, as well as guarding the sanctity are the real situation, the truth. The use of the word kemerdekaan and hak in a sentence is the form of affirmation because the two words with similar meanings are used together.

The third word is bangsa (usually translated as nation), which is the last word of the first sentence in the Preamble of the 1945 Constitution. With the sentence, the Preamble of the 1945 Constitution admits the existence of nation or, exactly, nations. The word bangsa is not the explanation of the word kemerdekaan and the word hak mentioned above. However, the word bangsa is a word or a concept that is explained by the words kemerdekaan and hak. Comprehending this relation in Islamic worldview is in line with what is mentioned in Al-Quran surah al-Hujurat verse 13 as follows:

"O Mankind! We have created you from a male and a female, and made you into nations and tribes, that you may know one another. Verily, the most honourable of you with Allah is that (believer) who has at-Taqwâ [i.e. he is one of the Muttaqûn (the pious)]. Verily, Allah is All-Knowing, All-Aware."

Therefore, the first sentence in the Preamble of the 1945 Constitution means that all nations are in the real situation and in the truth if guided by al-ilmu and wisdom, able to keep their sanctity, and able to refrain from the bad lust. Hence, the word bangsa in the sentence does not refer to the idea of nation that is born and evolving in the Western tradition, history, and culture or not accord with what is mentioned in Soekarno's speech on June $1^{\text {st }}, 1945$.

Interpreting the Preamble of the 1945 Constitution with the Islamic worldview will give certain consequences with a great impact. In Indonesian history, since Soekarno's regime until the (era of) Reformation, the interpretation has not 
been done. The rulers' choice, which can Guided Economy, and Indonesian be said as the choice to practice Personality) and Nasakom (Nationalism, hegemony over civil society, actually will Religion, and Communism) policy. The give certain consequences with a big power was then held by Soeharto who, impact as well. One of the most important since the beginning until the end of his things is the disconnection between the power, followed the policy of Political rulers and most of the Indonesian citizens who adhere to Islam based on the relations of Islamic scientific tradition, history, and culture. It is important to be explained why the rulers' choice is different from the interpretation of the 1945 Constitution.

It is because, after the Revolution, Indonesian national life went on to the process of choosing ideas to manage the national life. In the process done by Konstituante, Islamic ideas and Islam as suggested by Hurgronye to the Dutch Colonial Agreement (Moriyama, 2005). When Soeharto was replaced by Reformation Movement, the meaning of Islamic idea, which was manifested in the term masyarakat madani at that time, was repressed by Nurcholish Madjid by making masyarakat madani synonymous with civil society as explained in the beginning. Therefore, the real problem of Reformation is basically about the separation in Indonesian nation as a nationalism competed with each other without resulting in any agreement because Soekarno issued a presidential decree on July $5^{\text {th }}, 1959$, as an effort to make a consolidation and avoid friction as a consequence of the difference.

After issuing the decree, Soekarno issued Manipol/USDEK (Manifesto result of Politik Etis (Ethical Politics) in the beginning of the twentieth century (Karim, 1999; Latif, 2005; Noer, 1994).

A disclosure of this can be seen in, for example, the case of religious blasphemy with Basuki Cahaya Purnama or Ahok as the suspect and 212 Rally (Aksi 212). The case shows two different Politik/Undang-Undang Dasar1945, Sosialisme Indonesia, Demokrasi utterance in Pulau Pramuka. Ahok's Terpimpin, Ekonomi Terpimpin, dan supporters think that Ahok's utterance is Kepribadian Indonesia-Political Manifesto/the 1945 Constitution, court is a violation of human rights. Indonesian Socialism, Guided Democracy, Meanwhile, the mass of 212 Rally under 
the leadership of ulama (or ulemaIslamic scholars) and habib (or habeeb) regard Ahok's utterance as religious blasphemy. The difference of opinions and the various events following it has shown fundamental difference in national life that has not been overcome by Reformation.

\section{CONCLUSION}

Various opportunities that are possible to happen or be done after twenty years of Reformation. The choice that can be made to deal with the difference is to unite both sides. If the West and Islam are united as a worldview, a new worldview which is able to surpass both of them must be constructed. To realise this is something extremely difficult and it requires a classic effort. Pancasila as a formula or an ideology is impossible to be juxtaposed with the West and Islam that have been born and developed much bigger and longer.

The other choice is to make sure that a worldview is absolutely more superior that the other worldview. This enables Indonesia to develop its sociopolitical life with a guide from its chosen scientific tradition, history, and culture. Such a condition is never chosen in the sociopolitical practice in Indonesia. The split national condition makes Indonesia always inferior under the superiority of the colonial nations winning World War Two.

The inferiority will be maintained as long as the scientific tradition is still weak and even not built, especially when universities only play a role as educational institutions and not as scientific institutions. In this case, language is the biggest power which will determine the guide for the sociopolitical direction and change in Indonesia. The language disclosure can be seen from the quality of the writings published in the journals of social sciences, the curriculums of social sciences (including politics), as well as the direction of developing the disciplines of scientific classification in Indonesia.

Thus, after twenty years of Reformation, the political change in Indonesia can be faced with choices to be part of the West, or to be part of Islam, or to make something new (Pancasila, for instance), or to be neither of them.

\section{REFERENCES}

Al Attas, S. M. N. (1990). Islam Dalam Sejarah dan Kebudayaan Melayu. Petaling Jaya: ABIM.

Al Attas, S. M. N. (2000). Intellectual Imperialism: Definition, Traits and 
Problems. Southeast Asian Jurnal of Fairclough, N. (1995). Critical Discourse Social Science, 2(1), 23-45.

Al Attas, S. M. N. (2010a). Diskursus Analysis: The Critical Study of Alternatif dalam IImu Sosial Asia: Tanggapan terhadap Eurosentrisme. Jakarta: Mizan Publika.

Al Attas, S. M. N. (2010b). Islam dan Sekularism. Bandung: Pimpin. Language. New York: Longman.

Fukuyama, F. (2004). The End of History and The Last Man, Kemenangan Kapitalisme dan Demokrasi Liberal. Yogyakarta: Penerbit Qalam.

Arsil, Fitra., Harianto, Gregorius Seto., Tohari, Hajiriyanto Y., \& Alfian, A. (Ed.). (2016). Jurnal Ketatanegaraan (Volume 001, Desember 2016): Pembukaan UUD NRI Tahun 1945, Pembukaan Undang-Undang Dasar Negara Republik Indonesia Tahun 1945 Sebuah Bahasan Ringkas. Lembaga Pengkajian MPR RI.

Assyaukanie, L. (2011). Ideologi Islam dan Utopia, Tiga Model Negara Demokrasi di Indonesia. Jakarta: Freedom Institute.

Barton, G. (1999). Gagasan Islam Liberal di Indonesia. Jakarta: Paramadina.

Baso, A. (1999). Civil Society Versus Masyarakat Madani: Arkeologi Pemikiran Civil Society dalam Islam Indonesia. Bandung: Pustaka Hidayah.

Edwards, M. (2011). Civil Society. UK: Polity Press.

Gaus, A. A. F. (2010). Api Islam Nucholish Madjid: Jalan Hidup Seorang Visioner. Jakarta: Penerbit Buku Kompas.

Halliday, M. A. K., Ramlan, M., Hasan, R., \& Tou, A. B. (1992). Bahasa, konteks, dan teks: aspek-aspek bahasa dalam pandangan semiotik sosial. Gadjah Mada University Press.

Harvey, D. (2009). Neoliberalisme dan Restorasi Kelas Kapitalis. Yogyakarta: Resist Book.

Hefner, R. W. (2001). Civil Islam: Islam dan Demokratisasi di Indonesia. Yogyakarta: ISAI dan TAF.

Horkheimer, M., Adorno, T. W., \& Noeri, G. (2002). Dialectic of Enlightment: Philosophical Fragments. Stanford University Press.

Huntington, S. P. (1997). Gelombang Demokrasi Ketiga. Jakarta: Pustaka Utama Grafiti.

Karim, M. R. (1999). Negara dan Peminggiran Islam Politik. Yogyakarta: Tiara Wacana. 
Latif, Y. (2005). Intelegensia Muslim dan Kuasa: Genealogi Intelegensia Muslim Indonesia Abad ke 20. Bandung: Mizan.

Maula, T. (Ed.). (1999). Jika Rakyat Berkuasa: Upaya Membangun Masyarakat Madani Dalam Kultur Feodal. Pustaka Hidayah.

Moriyama, M. (2005). Semangat Baru: Kolonialisme, Budaya Cetak, dan Kesusateraan Sunda Abad ke 19. Kepustakaan Populer Gramedia.

Muchariman, R. (2016). Kuasa Hegemoni Wacana Masyarakat Madani (Civil Society) Nurcholish Madjid dan Perubahan Politik di Indonesia. Universitas Gajah Mada.

Noer, D. (1994). Gerakan Modern Islam di Indonesia 1900-1942. Jakarta: LP3ES.

Rauf, M., Hidayat, S., \& Gismar, A. M., \& Mulia, S. M. (2011). Demokrasi Indonesia: Ledakan Tuntutan Publik Vs. Inersia Politik. Jakarta: Kemenko Polhukam dan BPS.

Simon, R. (2004). Gagasan Gagasan Politik Gramsci. Yogyakarta: Pustaka Pelajar.

Smith, D. E. (1985). Agama dan Modernisasi Politik, Suatu Kajian Analitis. Jakarta: Rajawali Pers.
Suminto, A. (1985). Politik Islam Hindia Belanda. Jakarta: LP3ES.

Widodo, Jokowi., \& Kalla, M. J. (2014). Jalan Perubahan Untuk Indonesia yang Berdaulat, Mandiri dan Berkepribadian; Visi, Misi dan Program Aksi. Jakarta: KPU. 